\title{
Tribological Characteristics of TiC, TiN and TiC/TiN Coatings
}

\author{
Chan Yeal Jeon ${ }^{1^{*}}$ \\ ${ }^{1}$ Department of Automobile Management, Joongbu University \\ $\mathrm{TiC}, \mathrm{TiN}$ 과 $\mathrm{TiC} / \mathrm{TiN}$ 코팅의 트라이볼로지 특성 \\ 전찬열 ${ }^{*}$ \\ ${ }^{1}$ 중부대학교 공과대학 자동차관리학과
}

\begin{abstract}
The tribological properties of $\mathrm{TiC}$, TiN and TiC/TiN coatings on steels prepared by the cathodic-arc (CA) ion plating technique were investigated. Experiments were carried out on a tribo-test machine using a Falex journal $\mathrm{V}$ block system. The friction and wear characteristics of the coatings were determined by varying the applied load and sliding speed. The TiC, TiN and TiC/TiN coatings markedly increased the tribological characteristics of the surface. As far as a single layer coating was concerned, TiN goes better results than TiC. However, the TiC/TiN multilayer coating performed better than either single layer coating. The major factor in the improved performance of the multilayer coating was the role of $\mathrm{TiC}$ in improving the adhesion between the external TiN layer and the substrate steel

요 약 $\mathrm{CA}$ 이온도금기술에 의한 $\mathrm{TiC}$ 와 $\mathrm{TiN}$ 그리고 $\mathrm{TiC} / \mathrm{TiN}$ 코팅재를 비교하기 위하여 트라이볼로지 물성을 연구 하였다. 실험은 Falex journal V block 시스템을 이용한 터보시험기에서 수행하였다. 코팅재의 마찰과 마모특성은 작 용된 하중과 미끄럼 속도에 의하여 다양하게 결정되었다. $\mathrm{TiC}$ 와 $\mathrm{TiN}$ 그리고 $\mathrm{TiC} / \mathrm{TiN}$ 코팅재는 표면에서 트라이볼로 지 특성이 현저하게 증가하였다. 단층코팅에서는 $\mathrm{TiC}$ 보다 $\mathrm{TiN}$ 이 좋은 결과를 얻었다. 그러나, $\mathrm{TiC} / \mathrm{TiN}$ 의 다층코팅은 다른 어떤 단층코팅보다 좋은 성능을 보였다. 다층코팅의 성능이 향상된 핵심요소는 $\mathrm{TiN}$ 층 외부와 강 사이에서 부착 이 증가하게된 $\mathrm{TiC}$ 의 역할 때문이다.
\end{abstract}

Key Words : Coating, TiC(Titanium carbide), TiN(Titanium nitride), TiC/TiN, Tribology

\section{Introduction}

The tribological characteristics of a coating are governed by several factors including the hardness of the coating and the substrate, friction coefficient, coating wear resistance, contact temperature and chemistry. A number of coating methods are in use. To prolong the life of a tool, coatings of $\mathrm{TiC}$ and $\mathrm{TiN}$ are made by chemical vapor deposition (CVD) or physical vapor deposition (PVD). To increase the wear resistance, a multilayer coating of $\mathrm{TiC} / \mathrm{TiN}$ is used [1-5]. The ion plating with a high degree of ionization is used to increase the adhesion between coating and substrate[6-8]. Bertoncello et al.[9] studied the composition and microstructure of TiC, TiN and $\operatorname{Ti}(\mathrm{C}, \mathrm{N})$ deposited by an industrial ion-plating system. Guu et al.[10-11] investigated the tribological characteristics of titanium coating formed by ion plating. The authors studied TiC preparation methods[12] and the tribological properties of $\mathrm{TiC}$ and $\mathrm{TiN}$ coatings $[13,14]$.

In this study, the tribological performance of $\mathrm{TiC}, \mathrm{TiN}$ and $\mathrm{TiC} / \mathrm{TiN}$ films deposited on steels by a reactive ion plating method were investigated.

${ }^{*}$ Corresponding Author : Chan-Yeal Jeon(Joongbu Univ.)

Tel: +82-41-750-6754 email: cyjeon@joongbu.ac.kr

Received October 29, 2013 Revised January 6, 2014

Accepted March 6, 2014 


\section{Experimental}

Tests were performed at room temperature using a journal and V block tester (Falex, ASTMD 2625) lubricated with mineral oil lubricants. Friction, wear, scar temperature were measured for various carrying loads and speeds[15].

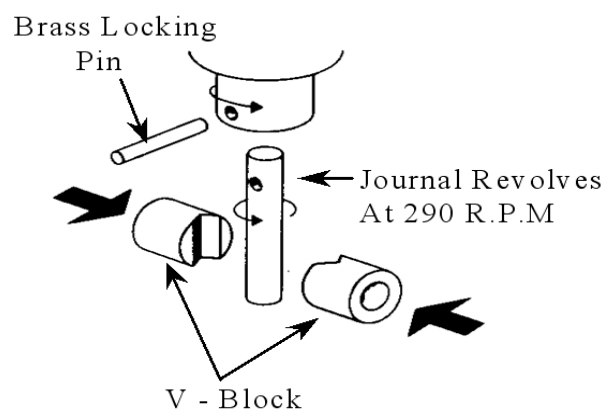

[Fig. 1] Exploded view of V-blocks and Journal arrangement

As shown in Fig. 1, a journal rotates against two stationary $\mathrm{V}$ blocks to give a four time contact in this configuration. The journal (AISI 3135) was $6.35 \mathrm{~mm}$ in diameter, $31.75 \mathrm{~mm}$ in length and HRb $87-91$ in hardness. The V block (AISI 4130) was HRc 20-24 in hardness and had a $96 \pm 1^{\circ}$ notch on its face. The characteristics of the journal and $\mathrm{V}$ block are summarized in Table 1.

[Table 1] Specimens Characteristics

\begin{tabular}{|c|c|c|c|}
\hline \multicolumn{2}{|c|}{ Materials } & $\begin{array}{c}\text { Journal } \\
\text { (AISI 3135) }\end{array}$ & $\begin{array}{c}\text { V block } \\
\text { (AISI 4130) }\end{array}$ \\
\hline \multirow{3}{*}{$\begin{array}{c}\text { Composition } \\
\text { mass (\%) }\end{array}$} & $\mathrm{C}$ & 0.15 & 0.30 \\
\cline { 2 - 4 } & $\mathrm{Si}$ & 0.20 & 0.20 \\
\cline { 2 - 4 } & $\mathrm{Mn}$ & 0.50 & 0.45 \\
\cline { 2 - 4 } & $\mathrm{Cr}$ & 0.35 & 0.80 \\
\hline \multicolumn{2}{|c|}{ Hardness (HRb, HRc) } & $87-91 \mathrm{HRb}$ & $20-24 \mathrm{HRc}$ \\
\hline \multicolumn{2}{|c|}{$\begin{array}{c}\text { Surface roughness } \\
\text { Ra (mm) }\end{array}$} & 0.15 & 0.15 \\
\hline
\end{tabular}

The coatings were deposited using a cathodic-arc (CA) ion plating method[16]. The pressure in the vacuum deposition chamber in which the coating was deposited was 10-4 10-5torr, the arc current was $100 \mathrm{~A}$, and the titanium ion bombardment was done at $1000 \mathrm{~V}$ bias voltage. The surface roughness $\mathrm{Ra}$ of the deposite layer was $0.3 \sim 0.4 \mathrm{~mm}$. its hardness HRc and thickness were , respectively, $55 \sim 63$ and $5 \mathrm{~mm}$. Table 2 lists the properties of $\mathrm{TiC}$ and $\mathrm{TiN}$ films. The $\mathrm{TiC} / \mathrm{TiN}$ multilayer coating was prepared by first coating the substrate with a $5 \mathrm{~mm}$ layer of TiN followed by a $5 \mathrm{~mm}$ layer of $\mathrm{TiC}$.

[Table 2] Properties of TiC and TiN films

\begin{tabular}{|c|c|c|}
\hline Property & TiC & TiN \\
\hline Microhardness (HRc) & 55 & 63 \\
\hline Thickness (mm) & 5 & 5 \\
\hline Roughness (mm) & 0.3 & 0.4 \\
\hline $\begin{array}{c}\text { Bonding strength } \\
(\mathrm{N} / \mathrm{cm} 2)\end{array}$ & 3,400 & 10,300 \\
\hline $\begin{array}{c}\text { Young's modulus } \\
(\mathrm{Mpa})\end{array}$ & $500^{\prime} 103$ & $260^{\prime} 103$ \\
\hline Density (gcm-3) & 4.9 & 5.2 \\
\hline
\end{tabular}

The samples were tested under an incrementally increasing load between $1.1 \sim 6.7 \mathrm{kN}$ for speed of $0.5 \sim$ $3.5 \mathrm{~m} / \mathrm{s}$. the surface temperature was continuously measured with a thermocouple inserted into a hole drilled through the V-block.

The lubricating mineral oil had a viscosity of 30.19 cst at $25^{\circ} \mathrm{C}$ and covered the entire friction surface. The wear volume was measured using a surface profilometer.

The worn surface was examined by scanning electron microscopy (SEM), and hardness was measured with a Rockwell hardness tester and a Vickers microhardness tester.

\section{Results and Discussion}

\subsection{The effect of load in friction}

The variation of friction coefficient of the substrate steel and TiC, TiN and TiC/TiN coatings with load is shown in Fig. 2.

The sliding speed was $1 \mathrm{~m} / \mathrm{s}$ for these test. It can be seen that the friction coefficient of the uncoated system increases with the load up to $3.3 \mathrm{kN}$, at which point it starts to increase rapidly, leading to the eventual failure beyond $4.5 \mathrm{kN}$. in the case of $\mathrm{TiC}, \mathrm{TiN}$ and $\mathrm{TiC} / \mathrm{TiN}$ coatings, however, the friction coefficient decreases with 
the load until a much higher load is applied. The TiC/TiN coating showed the lowest friction coefficient at $0.1 \sim$ 0.115 .

A dry, unlubricated surface usually follows the first law of friction, i.e. the friction coefficient is independent of load. The results of this work indicate that the uncoated steel surface follows this law, even when lubricated[17], up to a load at which seizure occurs. It is of interest, however, to note that $\mathrm{TiC}, \mathrm{TiN}$ and $\mathrm{TiC} / \mathrm{TiN}$ coatings display decreasing friction coefficient with increasing load.

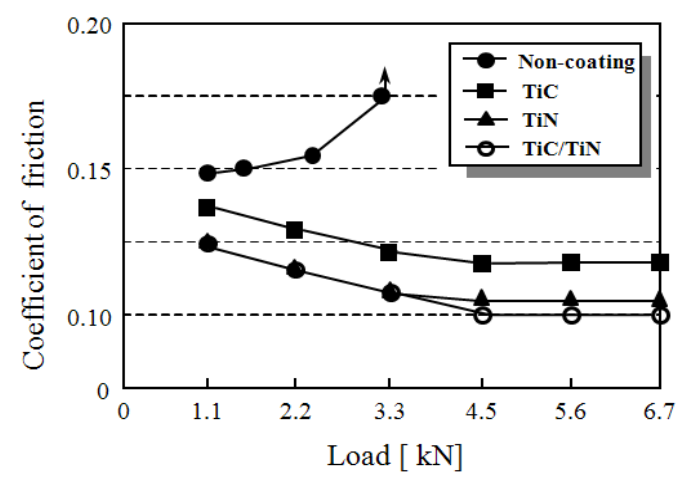

[Fig. 2] Coefficient of friction for load

\subsection{The effect of load on scar width}

Fig. 3 shows the effect of load on scar width. The coated surfaces show considerably smaller scar widths than the uncoated steel surface. Furthermore, the coatings keep the scar width relatively unchanged (or very slowly increasing) with load until cracks or delamination occurs. As seen in Fig. 4, the TiC coating developed cracks at a load of $4.4 \mathrm{kN}$, whereas Fig. 5 shows delamination of the TiN coating at $5.6 \mathrm{kN}$ loading. In contrast, the wear scars on multilayer coated specimens indicate considerably less wear than for the uncoated of single layer coated specimens. As shown in Fig. 6, the TiC/TiN multilayer coating had neither crack formation nor delamination at a load as high as $6.7 \mathrm{kN}$.

Zhang et al.[18] suggested that microcracks already present in the coating lead to separation into different sheets and along different directions. Porat[5] proposed that the many advantages of multilayer coatings, including their high strengths, derive from the effect of the layer interfaces in stopping crack propagation. Thus, the role of the intermediate $\mathrm{TiC}$ layer in the $\mathrm{TiC} / \mathrm{TiN}$ multilayer is to promote the adhesion between the TiN layer and the substrate.

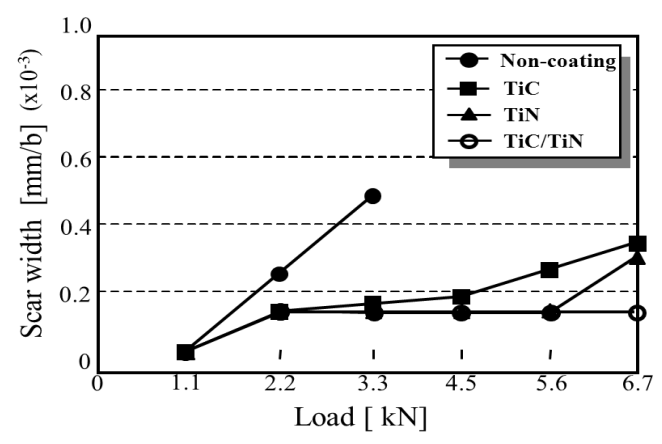

[Fig. 3] Scar width for load

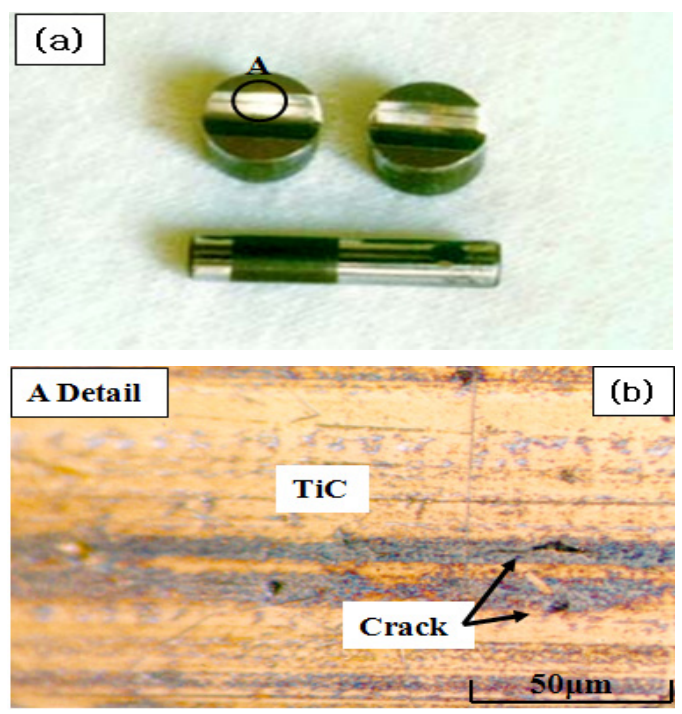

[Fig. 4] The SEM metallograph occurred crack of the TiC film $(4445 \mathrm{~N})$

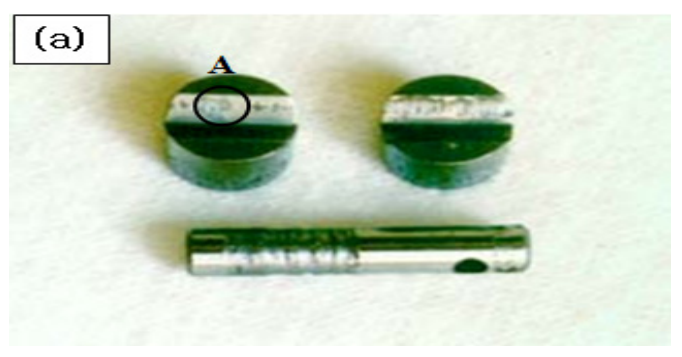




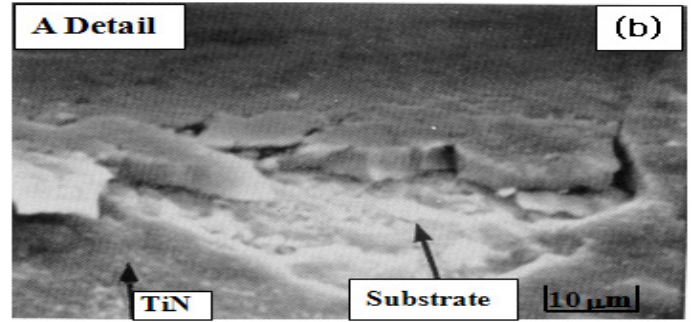

[Fig. 5] The SEM metallograph occurred delamination of the TiN film $(5556 \mathrm{~N})$

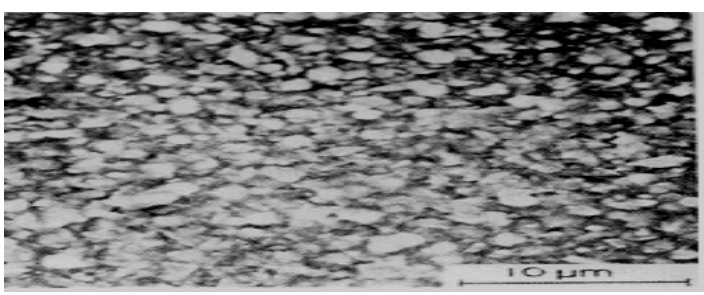

(a) The surface morphology

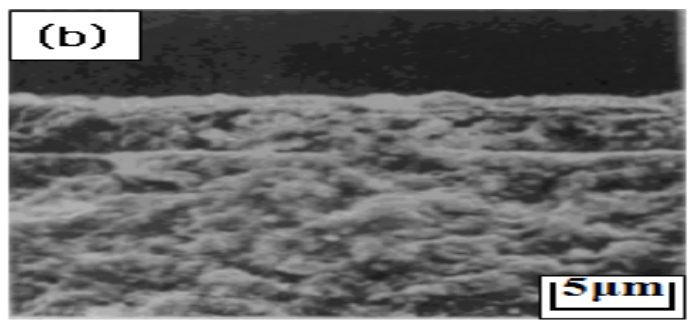

(b) The fracture cross section

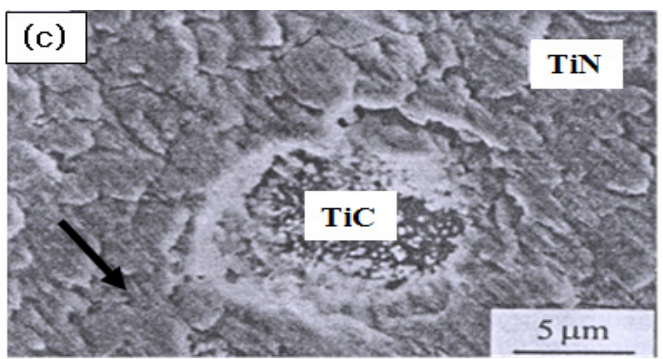

(c) Occurred delamination

[Fig. 6] The SEM metallograph of the TiC/TiN

\subsection{The effect of sliding speed on wear}

Fig. 7 shows the variation of the wear rate with sliding speed under a load of $2.2 \mathrm{kN}$. the normalized wear rate is defined as $\mathrm{Wr}=(\text { wear volume }(\mathrm{mm} 3) / \text { normal force }(\mathrm{N}))^{\times}$ sliding distance $(\mathrm{m})$. It is seen that all specimens display a rapid increase in wear rates up to a $1.5 \mathrm{~m} / \mathrm{s}$ sliding speed. The specimen without any coating suffers seizure and failure at a sliding speed of $3.0 \mathrm{~m} / \mathrm{s}$. In the case of
TiC and TiN coatings, the wear rate increased slowly beyond the sliding speed of $1.5 \mathrm{~m} / \mathrm{s}$, with TiN having a lower wear rate than $\mathrm{TiC}$. This is due to the fact that TiN has higher hardness than $\mathrm{TiC}$ and thus is less likely to deform plastically. The TiC/TiN coating showed a relatively unchanging wear rate beyond $1.5 \mathrm{~m} / \mathrm{s}$.

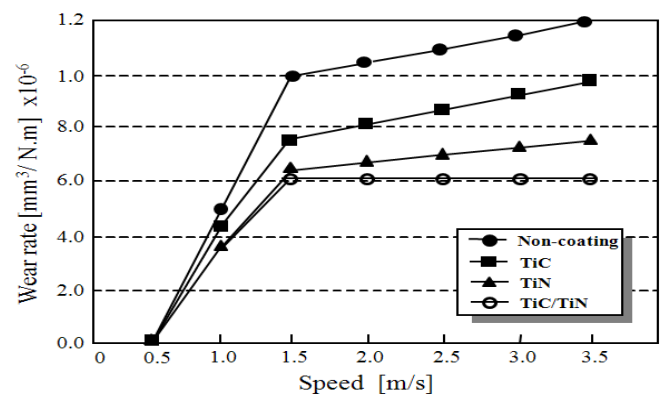

[Fig. 7] Wear rate for $\operatorname{speed}(2223 \mathrm{~N})$

\subsection{The effect of sliding speed on contact temperature of the coating}

The variation of contact temperature of $\mathrm{TiC}$, TiN and TiC/TiN coatings with speed is shown in Fig. 8. It is seen that the temperature of the uncoated surface increases sharply beyond a sliding speed of $1.0 \mathrm{~m} / \mathrm{s}$. On the other hand, with a TiC or TiN coating, the temperature reaches a maximum at a transition point at 1.5 and $2.0 \mathrm{~m} / \mathrm{s}$, respectively, and then decreases with sliding speed. For a $\mathrm{TiC} / \mathrm{TiN}$ coating, the transition point occurs at $1.5 \mathrm{~m} / \mathrm{s}$ speed, and the temperature remains relatively unchanged beyond this speed.

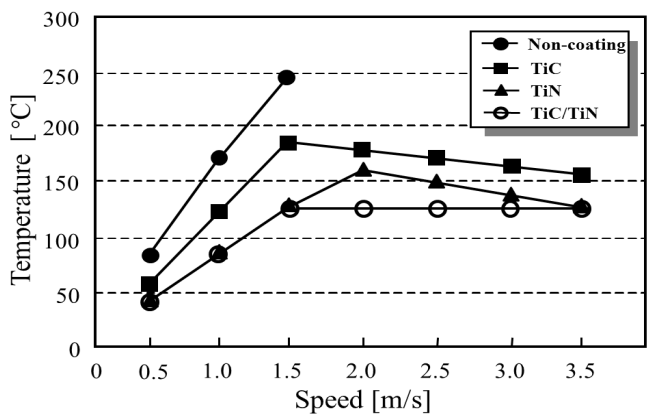

[Fig. 8] Temperature for speed(2223N)

\subsection{Relations between Friction and Wear}

In Fig. 9, wear rate is plotted against coefficient of 
friction. As expected, a lower coefficient of friction results in a lower wear rate. A similar result was reported by Vancoille et al.[19] for $\mathrm{TiN}$ and $\mathrm{TiC} / \mathrm{Ti}(\mathrm{C}, \mathrm{N}) / \mathrm{TiN}$ coatings sliding against $\mathrm{Al}_{2} \mathrm{O}_{3}$ surface.

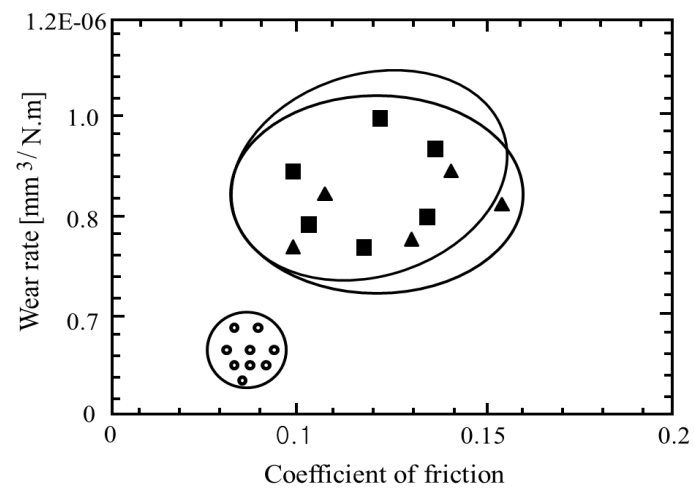

[Fig. 9] Wear rate for coefficient of friction

\section{Conclusion}

The tribological characteristics of $\mathrm{TiC}, \mathrm{TiN}$ and $\mathrm{TiC} / \mathrm{TiN}$ coatings were investigated. The results can be summarized as follows:

1. The TiC, TiN and TiC/TiN coatings, in that order, substantially lower the friction coefficient from the value for the uncoated surface of steel substrate.

2. The wear resistance of the TiC/TiN multilayer coating is higher than that of the $\mathrm{TiC}$ or TiN single layer coating, TiN providing better resistance than TiC. Temperature characteristics follow the same trend.

3. The coefficient of friction and surface temperature were also lowest for the $\mathrm{TiC} / \mathrm{TiN}$ multilayer coating than the $\mathrm{TiC}$ or $\mathrm{TiN}$ coating, at all sliding speeds and loads.

Overall, the TiC/TiN coating has the best tribological characteristics of the three coatings tested. In terms of friction coefficients, scar width, wear rate and contact temperature, the properties of $\mathrm{TiN}$ and $\mathrm{TiC} / \mathrm{TiN}$ coatings are quite similar before failure occurs. The important difference between these two coatings is that the $\mathrm{TiC} / \mathrm{TiN}$ multilayer fails at much more severe conditions than the
TiN layer. Thus, it is concluded that the role of the intermediate $\mathrm{TiC}$ layer in the $\mathrm{TiC} / \mathrm{TiN}$ multilayer is to promote the adhesion between the TiN layer and the substrate.

\section{References}

[1] J. Kusmierz., Tool. Prod, Vol. 55, No. 7, pp. 68 70, 1989

[2] N. J. Archer., The plasma-assisted chemical vapor deposition of TiC, TiN and TiCxN1-x, Thin solid films, Vol. 80, pp. 221 225, 1981 DOI: http://dx.doi.org/10.1016/0040-6090(81)90225-X

[3] J. Laimer, H. Stori, P. Rodhammer, J. Vac. Sci. Technol., Vol. A7, No. 5, pp. 2952 2959,1989 DOI: http://dx.doi.org/10.1116/1.576173

[4] A. A. Minevich., Wear of cemented carbide cutting inserts with multilayer Ti-based PVD coatings, Surf. Coat. Technol., Vol. 53, pp. 161 170,1992 DOI: http://dx.doi.org/10.1016/0257-8972(92)90118-T

[5] R. Porat, Surf. Eng., Vol. 8, No. 4, pp. 292 294, 1992 DOI: http://dx.doi.org/10.1179/sur.1992.8.4.292

[6] M. Sakaki, T. Sakakibara, IEEE Trans. Plasma Sci., Vol. 22, pp. 1049, 1994

DOI: http://dx.doi.org/10.1109/27.370251

[7] 7. G. I. Grigorov, I. N. Marter, M. V. Stoyanora, Low temperature growth of highly oriented TiN films by ion-assisted deposition, Thin Solid films, Vol. 198, pp. 169,1991

DOI: http://dx.doi.org/10.1016/0040-6090(91)90335-U

[8] P. J. Martin, R. P. Netterfield, J. Vac., Sci. Technol., Vol. A5, pp. 22, 1987

[9] R. Bertoncello, A. Casagrande, Surf. Interface Anal., Vol.187, pp. 525,1992

DOI: http://dx.doi.org/10.1002/sia.740180712

[10] Yeong Yan Guu, Jen Fin Lin, Chi-Fong Ai, The tribological characteristics of titanium carbonitride coatings prepared by cathodic-arc ion plating technique, Thin Solid Films, Vol. 287, pp. 16 24,1996 DOI: http://dx.doi.org/10.1016/S0040-6090(95)08496-7

[11] Yeong Yan Guu, Jen Fin Lin, Chi-Fong Ai, The tribological characteristics of titanium nitride, titanium carbonitride and titanium carbide coatings, Thin Solid Films, Vol. 302, pp.193 200,1997 DOI: http://dx.doi.org/10.1016/S0040-6090(96)09546-6

[12] S. G. Ko, C. W. Won, B. S. Chun, H. Y. Sohn, J. 
Mater. Sci., Vol..30, pp. $2825 \sim 2837,1995$

DOI: http://dx.doi.org/10.1007/BF00349651

[13] Y. H. Cho, S. M. Oh, B. G. Rhee, A Study on the Wear Characteristics of Ceramics Coating with PVD, J. KSME. A, Vol. 22, No.7, pp. 1229 1236,1998

[14] S. M. Oh, B. G. Rhee, Quantitative Analysis of Wear Debris for Surface Modification Layer by Ferrography, J. KSTLE, Vol. 15, No. 3, pp. 265 271,1999

[15] ASTM D 2625, Standard Test Method.

[16] C. F. Ai, J. Vacuum Sci. ROC., Vol. 6, No. 2, pp. 37,1993

[17] Xingzhong Zhao, Jiajun Liu, Tribol. Int., Vol. 30, No. 3, pp. $177 \sim 182,1997$

DOI: http://dx.doi.org/10.1016/S0301-679X(96)00034-5

[18] R. Zhang. Z, Z. Lin, Wear, Vol. 147, pp. 227 251,1991

DOI: http://dx.doi.org/10.1016/0043-1648(91)90182-T

[19] E. Vancoille, J. P. Celis, J. R. Roos, Studies on multilayer wear of CVD TiC-TiN multilayer composite coating, Tribol. Int., Vol. 26, No. 2, pp. 115 119,1993 DOI: http://dx.doi.org/10.1016/0301-679X(93)90019-W

Chan-Yeal Jeon

[Regular member]

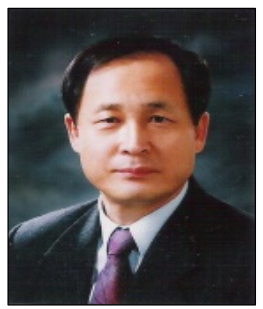

- Feb. 1976 : HanYang University Graduate (Mechanical Engin.).

- Feb. 1982 : Dankuk Univ., Mechanical engineering, MS

- Feb. 1990 : Dankuk Univ., Mechanical engineering. PhD

- Feb. $1993 \sim$ current : Joongbu Univ., Dept. of Automobile Management. Professor

$<$ Research Interests $>$

Heat and Fluid mechanics and Automobile Materials 